\title{
Biomassa dan Estimasi Simpanan Karbon pada Ekosistem Padang Lamun di Pulau Menjangan Kecil dan Pulau Sintok, Kepulauan Karimunjawa
}

\author{
Retno Hartati, Ibnu Pratikto, Tria Nidya Pratiwi* \\ Departemen Studi Ilmu Kelautan, Fakultas Perikanan dan Ilmu Kelautan, Universitas Diponegoro \\ Kampus Tembalang, Semarang 50275 Telp/Fax. 024-7474698 \\ Email: triapratiwi03@gmail.com
}

\begin{abstract}
Abstrak
Isu blue carbon telah menjadi perhatian dunia, melalui konsep UNEP 2009 yang telah memasukan vegetasi padang lamun sebagai penyerap karbon di lautan. Penyerapan karbon yang disimpan melalui sedimen dan jaringan pada lamun dalam bentuk biomassa. Penelitian yang dilakukan di Pulau Menjangan Kecil dan Pulau Sintok, Karimunjawa bertujuan untuk melihat tingkat kerapatan, tutupan dan penyerapan karbon yang tersimpan dalam biomassa jaringan lamun (akar, rhizoma dan daun). Kerapatan serta tutupan lamun diukur dengan melakukan sampling lapangan menggunakan metode transek kuadrat $1 \mathrm{~m}$ x 1m, identifikasi jenis lamun melihat panduan dari buku seagrasswatch. Hubungan kerapatan, biomassa dilakukan untuk melihat nilai kandungan karbon pada lamun. Sampling kerapatan, tutupan lamun dan nilai biomassa dilakukan pada semua titik, sedangkan untuk analisa karbon pada metode pengabuan dilakukan pada titik $50 \mathrm{~m}$ yang kemudian dikonversikan dengan nilai biomassa pada titik lainnya. Hasil pada penelitian ini ditemukan 8 jenis lamun, yaitu Enhalus acoroides, Thallasia hemprichii, Cymodocea rotundata, Cymodocea serrulata, Halodule uninervis, Halophila ovalis, Halophila minor, dan Halophila decipiens. Cymodocea rotundata mendominasi dikedua lokasi dengan kerapatan mencapai $1030 \mathrm{ind} / \mathrm{m} 2$. Nilai biomassa dibawah substrat $\left(554,54 \mathrm{gbk} / \mathrm{m}^{2}\right)$ lebih besar dibandingkan nilai biomassa diatas substrat $\left(342,72 \mathrm{gbk} / \mathrm{m}^{2}\right)$ diikuti nilai kandungan karbon dibawah substrat $\left(193,31 \mathrm{gC} / \mathrm{m}^{2}\right)$ yang lebih besar dibandingkan nilai kandungan karbon diatas substrat $\left(119,99 \mathrm{gC} / \mathrm{m}^{2}\right)$. Total kandungan karbon pada lokasi Pulau Menjangan Kecil adalah 32,18 ton karbon/ha dan Pulau Sintok adalah 4,18 ton karbon/ha.
\end{abstract}

Kata kunci: Kerapatan, Biomassa, Stok karbon, Lamun, Karimunjawa

\begin{abstract}
Blue carbon issue has become worldwide attention, UNEP through the concept of 2009 which has been to include vegetation seagrass beds as an absorbent of carbon in the ocean. The absorption of carbon that is stored through sediment and tissue in seagrass beds in the form of biomass. Research conducted on the island of Menjangan Kecil and island Sintok, Karimunjawa is to look at the level density, covering and absorption of carbon which is in biomass tissue seagrass ( the root, rhizoma and leaves ). Cover of seagrass density was measured by sampling the field using transect method $1 \mathrm{~m} x 1 \mathrm{~m}$ squares, identification of types of seagrass guidance from seagrasswatch book. Relationships density, biomass is made to see the value of the carbon content in the seagrass. Sampling density, seagrass cover and biomass values performed on all points, while carbon analysis on ashing method performed at the point of $50 \mathrm{~m}$ which is then converted to the value of biomass at another point. The results of the present study found 8 species of seagrasses that Enhalus acoroides, Thallasia hemprichii, Cymodocea rotundata, Cymodocea serrulata, Halodule uninervis, Halophila ovalis, Halophila minor, and Halophila decipiens. Cymodocea rotundata dominate in both locations with densities reaching $1030 \mathrm{ind} / \mathrm{m} 2$. Value biomass below the substrate $\left(554.54 \mathrm{gbk} / \mathrm{m}^{2}\right)$ indicates a value greater than the value of the biomass above the substrate $\left(342.72 \mathrm{gbk} / \mathrm{m}^{2}\right)$ followed by the value of the carbon content below the substrate $\left(193.31 \mathrm{gC} / \mathrm{m}^{2}\right)$ which is greater than the value carbon content above the substrate (119.99 $\left.\mathrm{gC} / \mathrm{m}^{2}\right)$. Total carbon content in locations Menjangan Kecil Island is 32.18 tons of carbon and Sintok island was 4.18 tons of carbon.
\end{abstract}

Keywords: Density, biomass, carbon stocks, seagrass, Karimunjawa Island

*Corresponding author

buloma.undip@gmail.com http://ejournal.undip.ac.id/index.php/buloma

Diterima/Received

Disetujui/Accepted
: 07-02-2017

: 30-03-2017 


\section{PENDAHULUAN}

Perubahan iklim yang drastis akibat kegiatan manusia telah menyumbangkan gas karbon dioksida yang cukup banyak ke udara dan atmosfer bumi. Karbon Dioksida $\left(\mathrm{CO}_{2}\right)$ memiliki kontribusi yang paling tinggi terhadap kandungan Gas Rumah Kaca yaitu sebesar 55\% dari emisi karbon oleh aktivitas manusia (IPCC, 2007).

UNEP, FAO dan UNESCO pada tahun 2009 telah memperkenalkan konsep blue carbon yaitu menekankan pentingnya ekosistem laut dan pesisir sebagai pengendali iklim. Konsep ini mengacu pada penyerapan karbon oleh marine ecosystems (mangrove, lamun, dan rawa payau/rawa masin) (Kennedy et al., 2010).

Ekosistem lamun merupakan salah satu ekosistem penting di laut, disamping terumbu karang dan mangrove sebagai pendukung kehidupan biota. Ekosistem lamun memiliki fungsi ekologi diantaranya adalah sebagai habitat (tempat hidup), tempat pemijahan (spawning ground), tempat pengasuhan (nursery ground), tempat pembesaran (rearing ground), dan tempat mencari makanan (feeding ground) dari berbagai biota, selain itu juga sebagai produsen primer, penangkap sedimen, serta pendaur zat hara (Kordi, 2011).

Menurut Fourqurean et al. (2012) ekosistem padang lamun dapat berkemampuan menyerap dan memindahkan jumlah besar karbon dari atmosfir setiap harinya, dan mengendapkannya dalam jaringan atau sedimen untuk waktu yang lama, sehingga keberadaan lamun dibumi sangat diperlukan sebagai jasa dalam penyerapan/sekuestrasi karbon (Carbon Sequestration).

Proses penyerapan karbon oleh ekosistem laut melalui proses biologis berupa fotosintesis. Proses fotosintesis berfungsi sebagai penyerap karbon di lautan, dimulai dari plankton yang mikroskopis maupun tumbuhan yang hanya hidup di pantai seperti mangrove, padang lamun, ataupun tumbuhan yang hidup di rawa payau (salt marsh). (Kawaroe, 2009).

Menurut penelitian yang dilakukan oleh Wicaksono (2012) total luas penutupan lamun di Kepulauan Karimunjawa sebesar 59,94 \% sehingga masih termasuk dalam kategori rapat, maka diperlukan suatu perhitungan biomassa dan estimasi stok karbon pada jaringan lamun yang terdapat di Kepulauan Karimunjawa. Pulau Menjangan Kecil dan Pulau Sintok menjadi perwakilan lokasi terhadap penelitian ini, dikarenakan Pulau Menjangan Kecil mewakili perairan sisi Barat sedangkan Pulau Sintok mewakili perairan sisi Timur dari Kepulauan Karimunjawa

Tujuan penelitian ini adalah untuk mengetahui jumlah spesies/jenis lamun, mengetahui kerapatan dan tutupan lamun, dan mengetahui nilai biomassa dan estimasi simpanan karbon dalam biomassa pada lamun yang berupa jaringan dibagian atas substrat (daun) dan dibagian bawah substrat (akar dan rhizoma) di Pulau Menjangan Kecil dan Pulau Sintok, Kepulauan Karimunjawa.

\section{MATERI DAN METODE}

Materi yang digunakan dalam penelitian ini adalah sampel lamun yang diambil di Pulau Menjangan Kecil dan Pulau Sintok pada tanggal 15 Mei 2016 sampai dengan 16 Mei 2016 yang kemudian di uji laboratorium pada tanggal $23 \mathrm{Mei}$ 2016 sampai dengan Selasa 7 Juni 2016 di Laboratorium Geologi Dasar Fakultas Perikanan dan Ilmu Kelautan Universitas Diponegoro. (Gambar 1.)

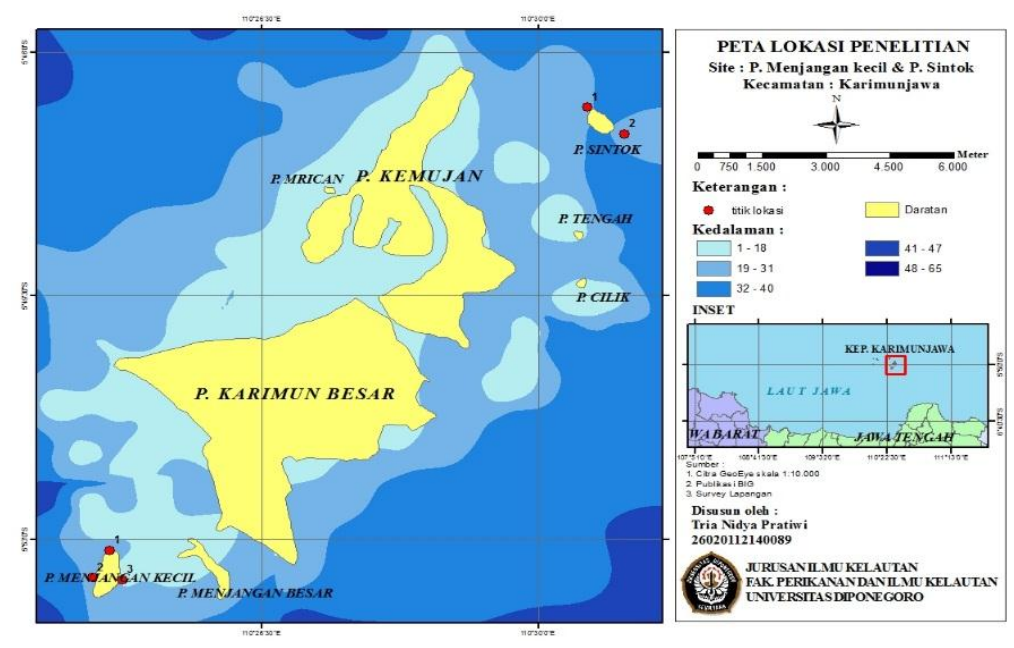

Gambar 1. Peta Lokasi Penelitian di Pulau Menjangan Kecil dan Pulau Sintok 
Pengamatan lamun meliputi jenis, kerapatan, dan persentase tutupan lamun. Pengamatan lamun dilakukan dengan cara menempatkan transek kuadran dengan ukuran $1 \mathrm{~m}$ $\mathrm{x} 1 \mathrm{~m}$ yang dibagi menjadi 16 sub plot berukuran $25 \mathrm{~cm}$ x $25 \mathrm{~cm}$ (Kenzie dan Campbell, 2003). Pengamatan jenis, perhitungan kerapatan dan persentase tutupan lamun digunakan buku indentifikasi lamun seagrasswatch yaitu, buku panduan penilaian secara cepat pada habitat lamun di Pasifik bagian Barat (Kenzie et al., 2001)

Pengambilan sampel lamun dilakukan dengan mencuplik lamun sampai pada kedalaman penetrasi akar dengan pemotongan rhizoma yang menjalar ke samping (batas luar kuadran/ transek) terlebih dahulu dengan menggunakan parang. Sampel lamun kemudian dibersihkan dan dikemas menjadi herbarium basah (Azkab,1999). Pencuplikan lamun dilakukan dengan 3 kali pengulangan terhadap lamun dengan morfologi besar sedangkan dilakukan 6 kali pengulangan terhadap lamun dengan morfologi kecil, dalam satu transek. Sampel lamun yang diambil merupakan lamun yang mendominasi pada transek tersebut (Graha, 2015).

Sampel lamun yang berupa herbarium basah, dipisahkan menurut jaringannya yaitu akar, rhizoma dan daun, kemudian dipotong-potong menjadi bagian terkecil dan ditimbang berat basahnya (Graha, 2015). Sampel lamun diukur berat basah dan berat keringnya maka didapatkan nilai biomassa pada setiap jaringan (Duarte, 1990).

Perhitungan kandungan karbon sampel jaringan lamun (daun, rhizoma dan akar) dianalisis dengan menggunakan metode pengabuan atau Loss On Ignition (LOI) (Helrich, 1990) yang dilakukan di Laboratorium Geologi Fakultas Perikanan dan Ilmu Kelautan Universitas Diponegoro. Perhitungan kandungan karbon ini hanya pada titik transek bagian tengah (titik 50) saja dari masingmasing garis transek, kemudian dikonversi dengan nilai biomassa di setiap titik 0 dan titik 100 dari masing-masing garis transek. Hasil konversi ke karbon keseluruhan kemudian dirata-rata dengan satuan $\mathrm{gC} / \mathrm{m}^{2}$ dan dikalikan dengan luasan lamun disuatu lokasi (Howards et al., 2014).

\section{Analisa Data}

Kerapatan Lamun dan Persentase Penutupan

Rumus yang digunakan untuk menghitung kerapatan lamun adalah dengan persamaan (Khouw, 2009):

Keterangan:
Di $=$ Kerapatan lamun jenis-i (ind $\left./ \mathrm{m}^{2}\right)$

$\Sigma$ ni = Jumlah tunas lamun jenis-i (ind)

$\mathrm{Ai}=$ Jumlah luas transek dimana lamun jenis-i ditemukan $\left(\mathrm{m}^{2}\right)$

Perhitungan penutupan jenis lamun pada tiap petak digunakan rumus menurut saito dan adobe (Kepmen LH, 2004):

$$
\mathrm{C}=\frac{\sum(\mathrm{Mix} \mathrm{fi})}{\sum \mathrm{fi}}
$$

Keterangan :

$\mathrm{C}=$ Persentase penutupan jenis lamun $\mathrm{i}$

$\mathrm{Mi}=$ Prosentase titik tengah dari kelas kehadiran jenis lamun $\mathrm{i}$

$\mathrm{Fi}$ =Banyaknya subpetak dengan kelas kehadiran jenis lamun i sama.

\section{Indeks Keanekaragaman}

Indeks keanekaragaman Shannon-Weinner dihitung berdasarkan Odum (1993), yang dirumuskan sebagai berikut :

$$
H^{\prime}=-\sum_{i=1}^{n}\left(p i \log ^{2} p i\right) \quad ; \quad p i=\frac{n i}{N}
$$

Keterangan:

$\mathrm{H}^{\prime}$ = Indeks keanekaragaman

$\mathrm{Ni}=$ Jumlah individu jenis ke- $\mathrm{i}$

$\mathrm{N}$ = Jumlah individu total

$\mathrm{Pi}=$ Proporsi frekuensi jenis ke-I terhadap jumlah total

\section{Indeks Keseragaman}

Nilai indeks keseragaman dihitung dengan menggunakan Simpson's Index (Odum, 1993), yaitu :

Keterangan:

$$
\mathrm{E}=\frac{\mathrm{H}^{\prime}}{\mathrm{H}_{\mathrm{Max}}} \quad ; \quad \mathrm{H}_{\max }=\log \mathrm{S}
$$

$\mathrm{E}=$ Indeks keseragaman

$\mathrm{H}^{\prime}=$ Indeks keanekaragaman

$\mathrm{S}=$ Jumlah spesies

\section{Indeks Dominansi}

Nilai indeks dominasi dihitung dengan menggunakan rumus menurut Odum (1993) :

Keterangan:

$$
\mathrm{D}=\sum_{\mathrm{i}=1}^{\mathrm{n}}(p i)^{2}
$$

$\mathrm{D}=$ Indeks dominasi Simpson

$\mathrm{Pi}=$ Proporsi frekuensi jenis ke-I terhadap jumlah total 


\section{Pengukuran Biomassa Lamun}

Rumus yang digunakan untuk menghitung biomassa ditunjukkan oleh persamaan menurut Duarte (1990):

$$
\mathrm{B}=\mathrm{W} \times \mathrm{D}
$$

Keterangan:

$\mathrm{B}=$ Biomassa Lamun (gram. $\mathrm{m}^{-2}$ )

$\mathrm{W}=$ Berat Kering sebuah Tunas Lamun (gram.tunas ${ }^{-1}$ )

$\mathrm{D}=$ Kepadatan Lamun (tunas. $\mathrm{m}^{-2}$ )

\section{Pengukuran Karbon Lamun}

Rumus yang digunakan untuk menghitung kandungan karbon jaringan lamun dengan metode pengabuan dapat dihitung dengan persamaan oleh Helrich (1990):

$$
\text { Kadar Abu }=\frac{c-a}{b-a} \times 100 \%
$$

Keterangan :

$\mathrm{a}=$ berat cawan

$\mathrm{b}=$ berat cawan + berat kering jaringan lamun

$\mathrm{c}=$ berat cawan + berat abu jaringan lamun

Bahan organik dihitung dengan metode pengabuan yaitu pengurangan berat saat pengabuan oleh Helrich (1990):

Kadar Bahan Organik $=\frac{[(b-a)-(c-a)]}{(b-a)} \times 100 \%$

Keterangan :

$\mathrm{a}=$ berat cawan

$\mathrm{b}=$ berat cawan + berat sampel

$\mathrm{c}=$ berat (cawan $+\mathrm{abu})$

Nilai kandungan karbon jaringan lamun dihitung dengan persamaan Helrich (1990):

$$
\text { Kandungan Karbon }=\frac{\text { Kadar Bahan Organik }}{1,724}
$$

Keterangan :

$1,724=$ konstanta nilai bahan organik

Nilai hasil kandungan karbon tersebut kemudian dirata-rata sebagai nilai kandungan karbon jaringan lamun (Graha, 2015).

\section{Total Stok Karbon}

Total stok karbon lamun dihitung dengan menggunakan rumus menurut Sulaeman et al. (2005):
Keterangan :

$$
\mathrm{Ct}=\Sigma(\mathrm{Li} \times \mathrm{ci})
$$

$\mathrm{Ct}=$ karbon total (ton)

$\mathrm{Li}=$ luas padang lamun kategori kelas $\mathrm{i}\left(\mathrm{m}^{2}\right)$

$\mathrm{Ci}=$ rata-rata stok karbon lamun kategori kelas $\mathrm{i}$ $\left(\mathrm{gC} / \mathrm{m}^{2}\right)$

\section{HASIL DAN PEMBAHASAN}

Penelitian dilakukan di dua lokasi Kepulauan Karimunjawa yaitu Pulau Menjangan Kecil dan Pulau Sintok yang mewakili sisi Barat dan sisi Timur Kepulauan Karimunjawa. Lokasi ini dipilih karena pada penelitian sebelumnya, Pulau Karimunjawa masih memiliki tingkat sebaran jenis dan kerapatan lamun yang tinggi. Berdasarkan hasil pengamatan lamun di kedua lokasi maka didapatkan 8 jenis lamun yang hidup dikedua lokasi penelitian, yaitu : Enhalus acoroides, Thallasia hemprichii ,Cymodocea rotundata, Cymodocea serrulata, Halophila decipiens, , Halophila minor, Halophila ovalis dan Halodule uninervis.

Perhitungan kerapatan lamun berhubungan dengan perhitungan biomassa lamun yang digunakan untuk memprediksi hasil karbon pada semua titik sampling kepadatan. Hasil perhitungan kerapatan individu dan persentase tutupan lamun disajikan dalam Gambar 2 dan 3.

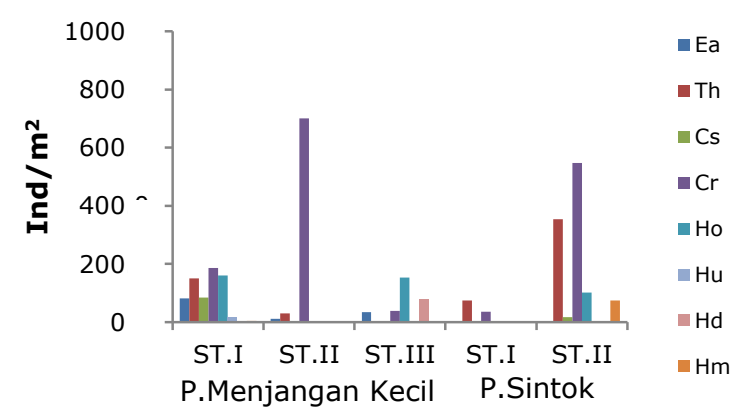

Gambar 2. Kerapatan lamun disetiap stasiun

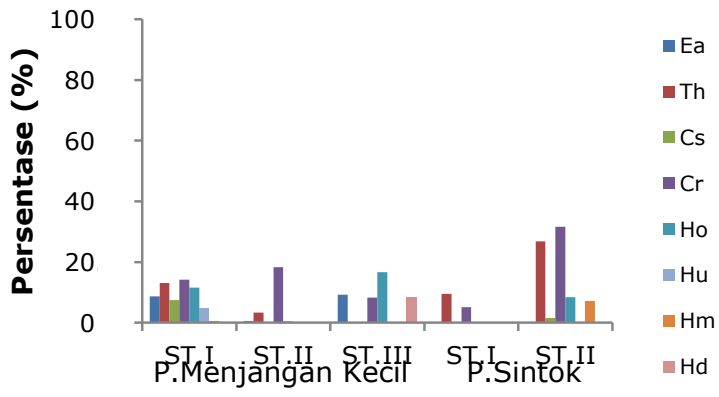

Gambar 3. Persentase tutupan lamun disetiap stasiun

Gambar 2 menjelaskan bahwa spesies $C$. rotundata memiliki tingkat kerapatan tertinggi 
pada ketiga stasiun yaitu stasiun II Pulau Sintok, stasiun I Pulau Menjangan Kecil dan stasiun II Pulau Menjangan Kecil. Gambar 3 menjelaskan grafik persentase tutupan lamun yang sejalan dengan jumlah kerapatan lamun yang ada pada titik tersebut.

\section{Indeks Ekologi Lamun}

Nilai indeks keanekaragaman dari semua stasiun berkisar $0,00-1,95$ jika dimasukkan kedalam pengakategorian nilai indeks keanekaragaman akan menunjukan bahwa disemua stasiun penelitian memiliki keanekaragaman yang sedang sampai rendah.

Nilai indeks keseragaman yang didapat dari lima stasiun menunjukan kategori dari rendah sampai ke tinggi. Nilai rata-rata indeks keseragaman berkisar antara 0,00-0,97.

Nilai Indeks Dominasi akan berbanding terbalik dengan nilai indeks keseragaman dan nilai indeks keanekaragaman. Nilai indeks dominasi kelima stasiun ini berikisar 0,26 - 1,00 yang artinya kelima stasiun ini memiliki dominasi ada dan tidak ada dominasi pada lokasi tersebut.

\section{Biomassa Lamun}

Total biomassa lamun yang didapat dari kedua lokasi yaitu 7,63-897,26 gbk $/ \mathrm{m}^{2}$. Nilai ini diduga didominasi oleh lamun $E$. acoroides, $T$. hemprichii, dan C. rotundata. Menurut Laffoley dan Grimsditch (2009), jenis lamun yang secara morfologi berukuran besar cenderung mengembangkan biomassa yang tinggi. $E$. acoroides memiliki morfologi yang paling besar diantara spesies lamun lainnya, sehingga diduga $E$. acoroides sebagai penyumbang biomassa yang tinggi. Kerapatan lamun $C$. rotundata dan $T$. hemprichii dibeberapa stasiun memiliki kerapatan yang tinggi dan persentase tutupan yang juga tinggi, walaupun morfologi lamun jenis ini lebih kecil dibandingkan dengan E. acoroides namun spesies E. acoroides memiliki kerapatan yang lebih rendah dibandingkan dengan spesies $C$. rotundata dan T. hemprichii. Al-Bader et al. (2014) menyatakan bahwa semakin banyak rimpang dan akar yang dapat menembus sedimen maka akan dapat menciptakan ruang pori pada substrat yang kemudian akan membantu dalam penyerapan nutrien dan pemasukan nutrisi pada rimpang juga substrat.

Berdasarkan Gambar 4 dan 5 biomassa dibawah substrat yaitu $3,38-554,54 \mathrm{gbk} / \mathrm{m}^{2}$ lebih besar dibandingkan dengan biomassa diatas substrat yaitu $2,79-342,72 \mathrm{gbk} / \mathrm{m}^{2}$, hal ini dikarenakan bahwa rhizoma mengandung banyak zat pati dan unsur hara dimana zat tersebut didistribusikan dari hasil fotosintesis yang disimpan pada bagian dibawah substrat, sehingga biomassa pada rhizoma dibawah substrat lebih tinggi dibandingkan dengan jaringan lainnya (Erftemeijer, 1993).

\section{Estimasi Kandungan Karbon pada Lamun}

Graha (2015) menyatakan bahwa variasi kandungan karbon lamun dipengaruhi oleh perbedaan biomassa antar jenis ataupun antar jaringan. Semakin tinggi kandungan biomassa pada lamun maka nilai kandungan karbon pada jaringan lamun juga semakin meningkat, yang artinya kandungan karbon berbanding lurus dengan kandungan biomassa pada lamun (Wardah, 2009). Sesuai dengan pernyatan sebelumnya, maka hasil yang didapat dari penelitian ini berbanding lurus pada nilai biomassa yang ada pada jaringan lamun. Total kandungan karbon berkisar antara 2,73 $301,80 \mathrm{gC} / \mathrm{m}^{2}$ (Tabel 1).

Biomassa lamun diduga didominasi oleh spesies $C$. rotundata, $T$. hemprichii, dan $E$. acoroides. maka kandungan karbon pada total karbon juga mempunyai kemungkinan didominasi oleh spesies yang sama.Kandungan karbon yang didapat dibawah substrat berkisar antara 1,15 193,31 $\mathrm{gC} / \mathrm{m}^{2}$ (Tabel 1) lebih besar dibanding dengan kandungan karbon diatas substrat yang berkisar antara $0,95-119,99 \mathrm{gC} / \mathrm{m}^{2}$ (Tabel 1), hal ini dikarenakan kandungan karbon dibawah substrat tidak terlalu terkena pengaruh oleh faktor fisik lingkungan dibandingkan dengan kandungan

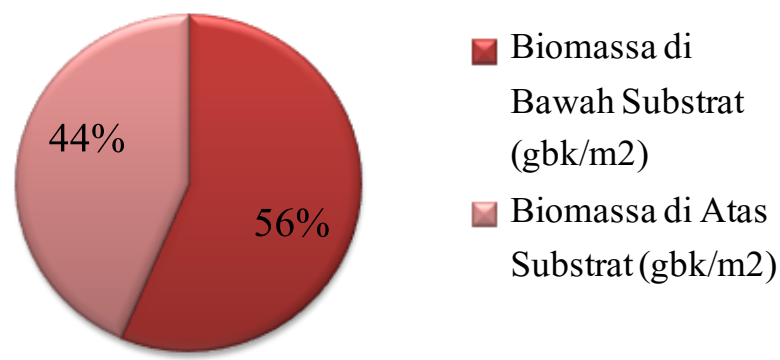

Gambar 4. Biomassa Pulau Menjangan Kecil

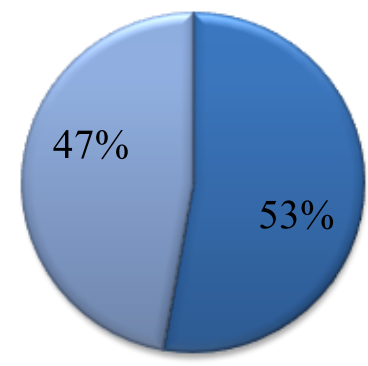

Biomassa di

Bawah Substrat

(gbk/m2)

Biomassa di Atas

Substrat $(\mathrm{gbk} / \mathrm{m} 2)$

Gambar 5. Biomassa Pulau Sintok 
Tabel 1. Estimasi Kandungan Karbon di Pulau Menjangan Kecil dan Pulau Sintok

\begin{tabular}{|c|c|c|c|c|c|c|c|c|c|c|c|}
\hline \multicolumn{6}{|c|}{ Pulau Menjangan Kecil } & \multicolumn{6}{|c|}{ Pulau Sintok } \\
\hline \multicolumn{6}{|c|}{ Kandungan Karbon $\left(\mathrm{gC} \mathrm{m}^{2}\right)$} & \multicolumn{6}{|c|}{ Kandungan Karbon $\left(\mathrm{gC} \mathrm{m}^{2}\right)$} \\
\hline $\mathbf{S T}$. & Line & Titik & $\begin{array}{c}\text { Karbon } \\
\text { Bawah } \\
\text { Substrat }\end{array}$ & $\begin{array}{c}\text { Karbon } \\
\text { Atas } \\
\text { Substrat }\end{array}$ & $\begin{array}{c}\text { Total } \\
\text { Karbon }\end{array}$ & ST. & Line & Titik & $\begin{array}{c}\text { Karbon } \\
\text { Bawah } \\
\text { Substrat }\end{array}$ & $\begin{array}{c}\text { Karbon } \\
\text { Atas } \\
\text { Substrat }\end{array}$ & $\begin{array}{c}\text { Total } \\
\text { Karbon }\end{array}$ \\
\hline \multirow{9}{*}{$\mathbf{I}$} & \multirow{3}{*}{$\mathbf{1}$} & $\mathbf{0}$ & 52,58 & 42,54 & 95,12 & \multirow{9}{*}{$\mathbf{I}$} & \multirow{3}{*}{$\mathbf{1}$} & $\mathbf{0}$ & 8,43 & 9,99 & 18,43 \\
\hline & & 50 & 50,76 & 52,48 & 103,24 & & & 50 & 10,39 & 14,62 & 25,01 \\
\hline & & 100 & 47,88 & 42,62 & 90,50 & & & 100 & 17,20 & 12,51 & 29,72 \\
\hline & \multirow{3}{*}{2} & $\mathbf{0}$ & 28,09 & 15,52 & 43,61 & & \multirow{3}{*}{2} & $\mathbf{0}$ & 13,67 & 13,77 & 27,44 \\
\hline & & 50 & 51,86 & 77,46 & 129,32 & & & 50 & 8,47 & 8,51 & 16,98 \\
\hline & & 100 & 99,52 & 49,93 & 149,46 & & & 100 & 5,36 & 2,52 & 7,88 \\
\hline & \multirow{3}{*}{3} & $\mathbf{0}$ & 75,88 & 64,69 & 140,57 & & \multirow{3}{*}{3} & $\mathbf{0}$ & 2,54 & 3,81 & 6,35 \\
\hline & & 50 & 131,06 & 96,37 & 227,44 & & & 50 & 2,06 & 3,86 & 5,93 \\
\hline & & 100 & 75,20 & 56,67 & 131,87 & & & 100 & 1,11 & 1,62 & 2,73 \\
\hline \multirow{9}{*}{ II } & \multirow{3}{*}{$\mathbf{1}$} & $\mathbf{0}$ & 193,31 & 108,49 & 301,80 & \multirow{9}{*}{ II } & \multirow{3}{*}{1} & $\mathbf{0}$ & 9,66 & 2,83 & 12,49 \\
\hline & & 50 & 9,76 & 9,33 & 19,09 & & & 50 & 3,58 & 4,12 & 7,70 \\
\hline & & 100 & 2,68 & 2,38 & 5,06 & & & 100 & 9,94 & 3,25 & 13,19 \\
\hline & \multirow{3}{*}{2} & $\mathbf{0}$ & 106,82 & 119,99 & 226,81 & & \multirow{6}{*}{3} & $\mathbf{0}$ & 4,11 & 2,05 & 6,16 \\
\hline & & 50 & 7,50 & 18,06 & 25,56 & & & 50 & 9,68 & 6,40 & 16,07 \\
\hline & & 100 & 1,15 & 5,40 & 6,56 & & & 100 & 8,36 & 5,39 & 13,75 \\
\hline & \multirow{3}{*}{3} & $\mathbf{0}$ & 119,06 & 82,52 & 201,58 & & & $\mathbf{0}$ & 5,62 & 6,84 & 12,46 \\
\hline & & 50 & 31,38 & 29,62 & 61,00 & & & 50 & 11,07 & 9,81 & 20,88 \\
\hline & & 100 & 2,16 & 1,49 & 3,65 & & & 100 & 11,71 & 8,08 & 19,78 \\
\hline \multirow{9}{*}{ III } & \multirow{3}{*}{$\mathbf{1}$} & $\mathbf{0}$ & 126,26 & 31,74 & 158,00 & & & & & & \\
\hline & & 50 & 26,95 & 13,32 & 40,26 & & & & & & \\
\hline & & 100 & 33,49 & 42,71 & 76,20 & & & & & & \\
\hline & \multirow{3}{*}{2} & $\mathbf{0}$ & 9,81 & 11,41 & 21,22 & & & & & & \\
\hline & & 50 & 3,08 & 1,35 & 4,43 & & & & & & \\
\hline & & 100 & 11,14 & 6,82 & 17,96 & & & & & & \\
\hline & \multirow{3}{*}{3} & $\mathbf{0}$ & 4,38 & 1,60 & 5,98 & & & & & & \\
\hline & & 50 & 8,87 & 4,07 & 12,94 & & & & & & \\
\hline & & 100 & 4,09 & 0,95 & 5,04 & & & & & & \\
\hline
\end{tabular}

karbon diatas substrat yang lebih dipengaruhi oleh faktor perairan seperti suhu dan lainnya (Supriadi, 2012). Kennedy et al. (2009) menyatakan bahwa kandungan karbon dibawah substrat akan tersimpan disedimen walaupun tunas pada lamun tersebut telah mati, sedangkan karbon diatas substrat hanya akan tersimpan jika tunas lamun masih tetap hidup.

Tabel 2. Perbandingan Nilai Estimasi Stok Karbon

\begin{tabular}{|c|c|c|c|c|}
\hline No & Lokasi & $\begin{array}{c}\text { Substrat } \\
\text { Bawah } \\
\text { (ton) }\end{array}$ & $\begin{array}{l}\text { Substrat } \\
\text { Atas } \\
\text { (ton) }\end{array}$ & $\begin{array}{c}\text { Total } \\
\text { Stok } \\
\text { Karbon } \\
\text { (ton) }\end{array}$ \\
\hline 1. & $\begin{array}{l}\text { Pulau } \\
\text { Menjangan } \\
\text { Kecil }\end{array}$ & 18,36 & 13,83 & 32,19 \\
\hline 2. & $\begin{array}{l}\text { Pulau } \\
\text { Sintok }\end{array}$ & 2,27 & 1,91 & 4,18 \\
\hline
\end{tabular}

Pulau Sintok memiliki kandungan estimasi stok karbon yang lebih kecil dibandingkan oleh Pulau Menjangan Kecil, hal ini diduga karena faktor lingkungan dan proses fisiologis akan berdampak pada penyerapan karbon juga laju respirasi pada lamun (Graha, 2015). Pulau sintok memiliki dua spesies lamun yang mendominasi yaitu $C$. rotundata dan $T$. hemprichii, sehingga penyerapan karbon hanya dipengaruhi oleh kedua spesies tersebut.

Pulau Menjangan Kecil juga didominasi oleh spesies lamun yang sama seperti yang terdapat pada Pulau Sintok, namun di Pulau Menjangan Kecil masih terdapat spesies E. acoroides walaupun tidak mendominasi tetapi diduga spesies $E$. acoroides menjadi penyumbang karbon tertinggi di Pulau Menjangan Kecil.

Bahan organik juga berpengaruh sebagai faktor penyerapan karbon dibawah substrat. Seperti yang dikemukakan oleh Yunitha (2015) bahwa penyerapan karbon organik dipengaruhi oleh besaran butiran substrat, karena butiran substrat yang lebih besar menurunkan kemampuan substrat tersebut menyerap karbon organik. Pulau Menjangan Kecil memiliki substrat yang lebih kecil dibandingkan dengan substrat di Pulau Sintok yang lebih besar, sehingga hal ini juga menjadi 
faktor tingginya kandungan karbon di Pulau Menjangan Kecil daripada di Pulau Sintok. Christon (2012) menambahkan bahwa besarnya biomassa lamun pada substart yang lebih kecil diakibatkan oleh efek positif terhadap sistem penyerapan nutrien, sedangkan substrat yang lebih besar (kasar) akan terjadi penurunan nutrien dan bahan organik.

\section{KESIMPULAN}

Terdapat 8 spesies lamun di kedua lokasi. Lamun Cymodocea rotundata memiliki dominasi tertinggi pada kedua lokasi penelitian, karena kerapatannya mencapai $1030 \mathrm{ind} / \mathrm{m}^{2}$ dan Thalassia hempricii adalah mendominasi kedua, karena kerapatannya mencapai 424 ind $/ \mathrm{m}^{2}$. Rata-rata persentase tutupan lamun dari kelima stasiun pada kedua lokasi penelitian adalah 14,13 - 32,58\%.

Nilai kandungan biomassa dibawah substrat lebih besar dibandingkan dengan biomassa. Begitu juga dengan nilai estimasi kandungan karbon dibawah substrat lebih besar dibandingkan dengan nilai estimasi kandungan karbon diatas substrat. Pulau Menjangan Kecil memiliki luasan lamun dan penyerapan karbon yang lebih tinggi (32,18 ton karbon) dibandingkan dengan Pulau Sintok (4,18 ton karbon).

\section{DAFTAR PUSTAKA}

Al-Bader, D.A., Shuail, D.A., Al-Hasan, R. dan Suleman, P. 2014. Intertidal Seagrass Halodule uninervis : Factor Controlling its Density, Biomass and Shoot Length. Kuwait Journal Science. (41): 171-192.

Azkab, M.H. 1999. Pedoman Inventarisasi Lamun. Oseana. 24(1):1-16.

Christon. 2012. Pengaruh Tinggi Pasang Surut Terhadap Pertumbuhan dan Biomassa Daun Lamun Enhalus acoroides di Pulau Pari Kepulauan Seribu Jakarta. Jurnal Universitas Padjajaran. 3(3):287-294.

Duarte, C.M. 1990. Seagrass Nutrient Content. Mar. Ecol. Prog. Ser., 67:201-207.

Erftemeijer, P.L.A., Osinga, R. and Mars, A.E. 1993. Primary Production of Seagrass Beds in South Sulawesi (Indonesia): a Comparison of Habits, Method and Species. Aquat Bot., 46: 67-90.

Fourqurean, J.W., Duarte, C.M., Kennedy, H., Marba, N., Holmer, M., Matoe, M.A., Apostolaki, E., Kendrick, G.A., Jensen, D.K., McGlathery, K.J., and Serrano, O. 2012. Seagrass Ecosystems as a Globally Significant Carbon Stock. Nature Geoscience. pp 1-5.
Graha, Y.I. 2015. Simpanan Karbon Padang Lamun di Kawasan Pantai Sanur, Kota Denpasar. [Thesis]. Program Pascasarjana, Universitas Udayana, Bali.

Helrich, K. 1990. Method of Analysis of The Association of Official Analytical Chemists. $5^{\text {th }}$ ed. Virginia.

Howard, J., Hoyt, S., Isensee, K., Telszewski, M., and Pidgeon, E. (eds.). (2014). Coastal Blue Carbon: Methods for Assessing Carbon Stocks and Emissions Factors in Mangroves, Tidal Salt Marshes, and Seagrasses. Conservation International, Intergovernmental Oceanographic Commission of UNESCO, International Union for Conservation of Nature. Arlington, Virginia, USA.

IPCC [Climate Change]. 2007. The Physical Science Basic, Contribution of Working Group I to The Fourth Assessment Report of the Intergovermental Panel on Climate Change.

Kawaroe, M. 2009. Perspektif Lamun Sebagai Blue Carbon Sink di Laut. Dalam: Lokakarya Nasional I Pengelolaan Ekosistem Lamun Tanggal 18 November 2009. Jakarta, Indonesia.

Kennedy, H. and Bjork, M. 2009. Seagrass Meadows. In: Laffoley D.D.A and Grimsditch G. (Eds). The Management of Natural Coastal Carbon Sinks. Glan: IUCN.

Beggins, J., Duarte, C.M., Fourqurean, J.W. and Holmer, M. 2010. Seagrass Sediments as a Global Carbon Sink: Isotopic Constraints. Global Biogeochemical Cycles.

Keputusan Menteri Lingkungan Hidup No.51. 2004. Baku Mutu Air Laut Untuk Biota Laut.

Khouw, A.S. 2009. Metode dan Analisa Kuantitatif dalam Bioteknologi Laut. Pusat Pembelajaran dan Pengembangan Pesisir dan Laut. Jakarta.

Kordi, K.H.G.M. 2011. Ekosistem Lamun (Seagrass) : Fungsi, Potensi, dan Pengelolaan. PT. Rineka Cipta, Jakarta.

Laffoley, D. and Grimsditch, G. 2009. The Management of Natural Coastal Carbon Sinks. IUCN, Gland Switzerland.

Mc Kenzie, Campbell, S.J. \& Roder, C.A. 2003. Seagrasswatch: Manual for Mapping and Monitring Seagrass Resources by Community (citizen) Volunteers. $2^{\text {nd }}$ ed. The state of Queensland, Department of Primary Industries, CRC Reef, Queensland, pp 104. www.seagrasswatch.org (28 April 2016). 
Odum, E. P. 1998. Dasar-dasar Ekologi. $3^{\text {rd }}$ ed. Universitas Gadja Mada, Yogyakarta.

Sulaeman, Suparto dan Eviati. 2005. Petunjuk Teknis Analisis Tanah, Tanaman, Air dan Pupuk. Balai Penelitian Tanah, Badan Penelitian dan Pengembangan Pertanian, Departemen Pertanian, Bogor.

Supriadi, Richardus F., Kaswadji, Dietrich G., Bengen, dan Malikusworo H. 2012. Stok dan Neraca Karbon Komunitas Lamun di Pulau Barranglompo, Makassar. Ilmu Kelautan. (1): 1-10.

Wardah., B. Toknok., dan Zulkaidhah. 2009. Persediaan Karbon Tegakan Agroforestri di
Zona Penyangga Hutan Konservasi Taman Nasional Lore Lindu, Sulawesi Tengah. [Penelitian Strategi Nasional]. Universitas Tadulako, Palu, Sulawesi Tengah.

Wicaksono, S.G. dan S.T.H. Widianingsih. 2012. Struktur Vegetasi dan Kerapatan Jenis Lamun di Perairan Kepulauan Karimunjawa Kabupaten Jepara. Ilmu Kelautan. (2):1-7.

Yunitha, Alpinina. 2015. Kandungan C-Organik pada Lamun Berdasarkan Habitat dan Jenis Lamun di Pesisir Desa Bahoi Kabupaten Minahasa Utara, Sulawesi Utara. [Thesis]. Sekolah Pascasarjana, Institut Pertanian Bogor, Bogor. 